\section{Encounter of plastic} surgeons with pentazocine abuse: Lack of awareness or information overloaded

Sir,

The past of medicine is studded with examples of substance abuse. Pentazocine is one such drug labelled "a drug of concern" due to its addiction potential. The situation is even more alarming in the more versed group, the medics and paramedics. Pharmacokinetics range from potent analgesic action and subjective pleasurable effects at lower doses, to unpleasant and psychotomimetic effects as dose is increased. The maximum permissible analgesic dose in adult by oral route is $600 \mathrm{mg}$ daily, by intravenous route is $30 \mathrm{mg} / \mathrm{dose}$ and $360 \mathrm{mg}$ daily and by intramuscular or subcutaneous route is $60 \mathrm{mg} / \mathrm{dose}$ and $360 \mathrm{mg}$ daily. It starts its action within 5-20 min and its action fades within 1-3 $\mathrm{h} .{ }^{[1]}$ We present another appalling suffering of this medical personnel. He presented with non-healing ulcers ${ }^{[2 \mid}$ over both legs, $15 \mathrm{~cm} \times 5 \mathrm{~cm}$ each, copious purulent discharge, necrotic tissues, margins undermined, surrounding brawny induration, foot drop bilaterally and florid osteomyelitis [Figures 1 and 2]. 


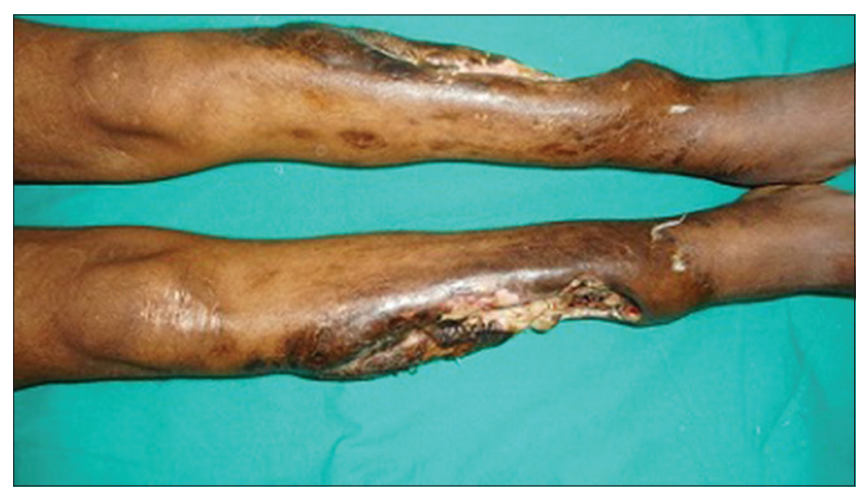

Figure 1: Deep ulcers exposing bone on bilateral legs with a halo of hyperpigmentation, brawny oedema and foot drop

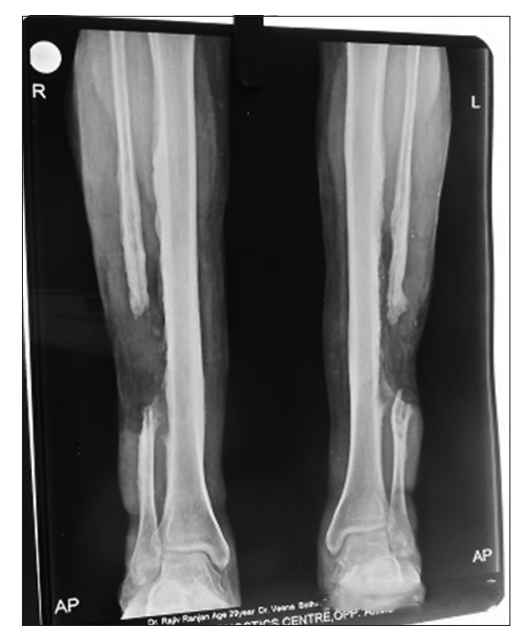

Figure 2: Anteroposterior view of X-ray film showing osteomyelitis tibia and fibula both legs

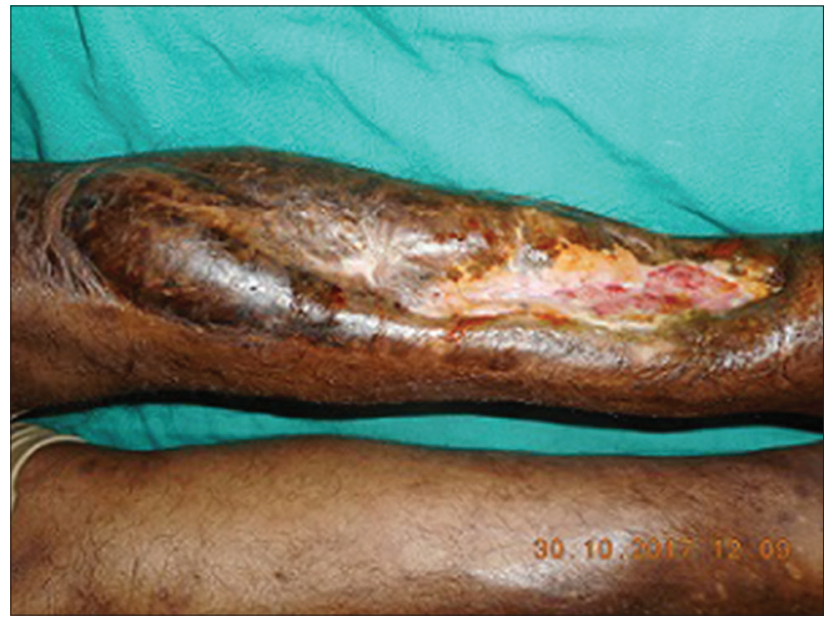

Figure 3: Ulcer in healing phase after debridement and negative pressure dressings; further being planned for a flap cover

Sensations and peripheral pulsations were normal. Due to the inevitable support of peers, it became almost impossible for his family to refrain him from the drug. The ulcers at the same site were thrice debrided and grafted earlier, which recurred at the same sites due to a repeated inclination for the drug [Figure 3]. The laboratory investigations were within normal limits, except for anaemia. Pus culture and tissue biopsy were negative.

The role of plastic surgeon is to halter the process of local tissue destruction and instituting methods of ulcer healing. These wounds are mostly polymicrobial, so broad-spectrum antibiotics are always advisable, in the presence of signs of bacteraemia or positive cultures. Irrigation with normal saline or diluted povidone iodine, or hypochlorous acid, ulcer debridement (sharp, blunt, surgical, chemical and biodebridement) to remove devitalised tissue from ulcer; accelerates the healing process. Negative pressure wound therapy helps in reducing oedema, exudates, bacterial load, helps in regeneration of granulation tissue and neovascularisation. Besides, autologous platelet-rich plasma infusion, $\mathrm{O} 2$ Misly therapy with $100 \% \mathrm{O}_{2}$ alternatively with water vapour and antibiotic; low-level LASER therapy; use of topical growth factors; hyperbaric $\mathrm{O} 2$ therapy; all have anti-inflammatory and regenerative capability in ulcer healing. Not to mention, the choice of therapy has to be individualised. Skin grafts or sorts of flaps are various options available, if bare bone, tendons are visible. The fatal outcomes with pentazocine abuse have compelled to review the precautionary measures, in special risk group-medical and paramedical professionals ${ }^{[3,4]}$ and those having a personal or family history of diabetes mellitus.

\section{Financial support and sponsorship Nil.}

\section{Conflicts of interest}

There are no conflicts of interest.

Neeti Neha, Veena Singh, Nandesh Kumar

Department of Burns and Plastic Surgery, All India Institute of Medical Sciences, Patna, Bihar, India

Address for correspondence: Dr. Neeti Neha,

Room No. 604, New PG 1 Hostel, All India Institute of Medical Sciences, Phulwarisharif, Patna, Bihar - 801 507, India.

E-mail: neeti.neha86@gmail.com

\section{REFERENCES}

1. Parks DL, Perry HO, Muller SA. Cutaneous complications of pentazocine injections. Arch Dermatol 1971;104:231-5.

2. Chambers CD, Inciardi JA, Stephens RC. A critical review of pentazocine abuse. HSMHA Health Rep 1971;86:627-36.

Indian Journal of Plastic Surgery Volume 51 Issue 2 May-August 2018 
3. Kumar D, GuptaA, Sharma VP, Yadav G, Singh A, VermaAK, et al. Pentazocine-induced contractures: Dilemma in management. Indian J Pharmacol 2015;47:451-3.

4. Palestine RF, Millns JL, Spigel GT, Schroeter AL. Skin manifestations of pentazocine abuse. J Am Acad Dermatol 1980;2:47-55.

This is an open access journal, and articles are distributed under the terms of the Creative Commons Attribution-NonCommercial-ShareAlike 4.0 License, which allows others to remix, tweak, and build upon the work non-commercially, as long as appropriate credit is given and the new creations are licensed under the identical terms.

\begin{tabular}{|l|l|}
\hline \multicolumn{2}{|c|}{ Access this article online } \\
\hline Quick Response Code: & Website: \\
\hline & www.ijps.org \\
\cline { 2 - 2 } & DOl: \\
\hline
\end{tabular}

How to cite this article: Neha N, Singh V, Kumar N. Encounter of plastic surgeons with pentazocine abuse: Lack of awareness or information overloaded. Indian J Plast Surg 2018;51:250-2.

$\odot 2018$ Indian Journal of Plastic Surgery | Published by Wolters Kluwer - Medknow 